\title{
COVID-19: A CENTENNIAL PANDEMIC FROM ORIGIN TO CLINICAL TRIALS
}

\author{
Ruddhida R VIDWANS ${ }^{1}$, Manendra Babu LANKADASARI ${ }^{2 *}$ \\ ${ }^{1} \mathrm{PhD}$ Research Scholar, Department of Microbiology, Jain University, Bangalore, India \\ ${ }^{2}$ Independent Researcher, Dr. No: 6/30, PedhaVeedi, Gudiwada, Andhra Pradesh, India
}

\author{
*Correspondence: \\ Manendra Babu LANKADASARI \\ lamb.jan90@gmail.com
}

Received: 18 May 2020; Accepted: 10 June 2020; Published: 30 June 2020

\begin{abstract}
In December 2019, an unexpected interaction of coronavirus with human's occurred for the third time in history after Severe Acute Respiratory Syndrome (SARS) in 2002-2003 and Middle East Respiratory Syndrome (MERS) in 2012. Soon the virus was confirmed as SARS-CoV-2, and the severity of its transmission lead the World Health Organization to declare it as World Pandemic. Due to its highly contagious nature, new methods like social distancing, self-hygiene and quarantine were being adopted by many countries to halt the transmission. Due to the dearth in specific therapeutics and/or vaccines against Coronavirus Disease (COVID-19), a significant thrust in drugs and vaccine discovery was ratified by all the nations. The current review comprehensively details about the emergence and molecular pathogenesis with an interesting timeline which notes all the major events during this crisis. Given the potential general readers and health workers, the symptoms and diagnostic approaches were simplified. Emphasis was given to therapeutic approaches and clinical trials section to support the translational research and to cope up with the viral outbreak.
\end{abstract}

Keywords: COVID-19, Coronavirus, Clinical trials, Pandemic, Infection.

\section{Introduction}

It all started with the rise in pneumonialike cases from the hospitals located in Wuhan, Hubei province, China. The transmission of this was identified from a local Huanan Seafood wholesale market, which is notoriously known for its selling of live and wild animals which were considered a delicacy in many Chinese houses. The market was closed and the researchers soon identified the novel coronavirus. The suspension of Chinese The other coronavirus family members, which caused well-known diseases, are the Middle East Respiratory Syndrome (MERS) and
Spring Festival by the authorities and quarantining the Wuhan city and later the entire Hubei province has helped to stop the further transmission of viral disease. On February 11th 2020, the pandemic was named as Coronavirus Disease 2019 (COVID-19 Disease) by the WHO which was also classified as "SARSCoV-2" (Severe acute respiratory syndromecoronavirus- 2 virus) by the International Virus Classification Commission (Zhou et al., 2020). Severe Acute Respiratory Syndrome (SARS) (Wit et al., 2016). By June $9^{\text {th }} 2020$, at least 188 countries and territories reported COVID- 
19 cases with worst-hit countries being the United States of America, Brazil, Russia, Spain, UK, India, Italy, Peru and Germany and the numbers dynamically changing day by day (Worldometer Corona, 2020). Being a developed nation with a highly efficient health care system, the USA recorded the highest cases and fatalities and is leading. It is followed by Brazil, Russia, Spain and UK (Fig. 1) (Worldometer Corona, 2020). Although, China has managed to reduce the number of active COVID-19 patients by following stringent quarantine measures, it is facing wide criticism for the projected number of infected patients. In this review, we attempted to explain the origin, evolution and molecular pathogenesis of the virus, with more emphasis on treatment strategies and clinical trials. The below information is based on the recent advancement in the research on COVID-19.

\section{Origin}

By the late November 2019, the preliminary reports about COVID-19 were noticed from the local hospitals in Wuhan, China. Several pulmonologists identified the disease as virus-initiated pneumonia based on clinical symptoms and lung radiographs. Preliminary epidemiological studies linked all the cases to their exposure to local Huanan seafood market.

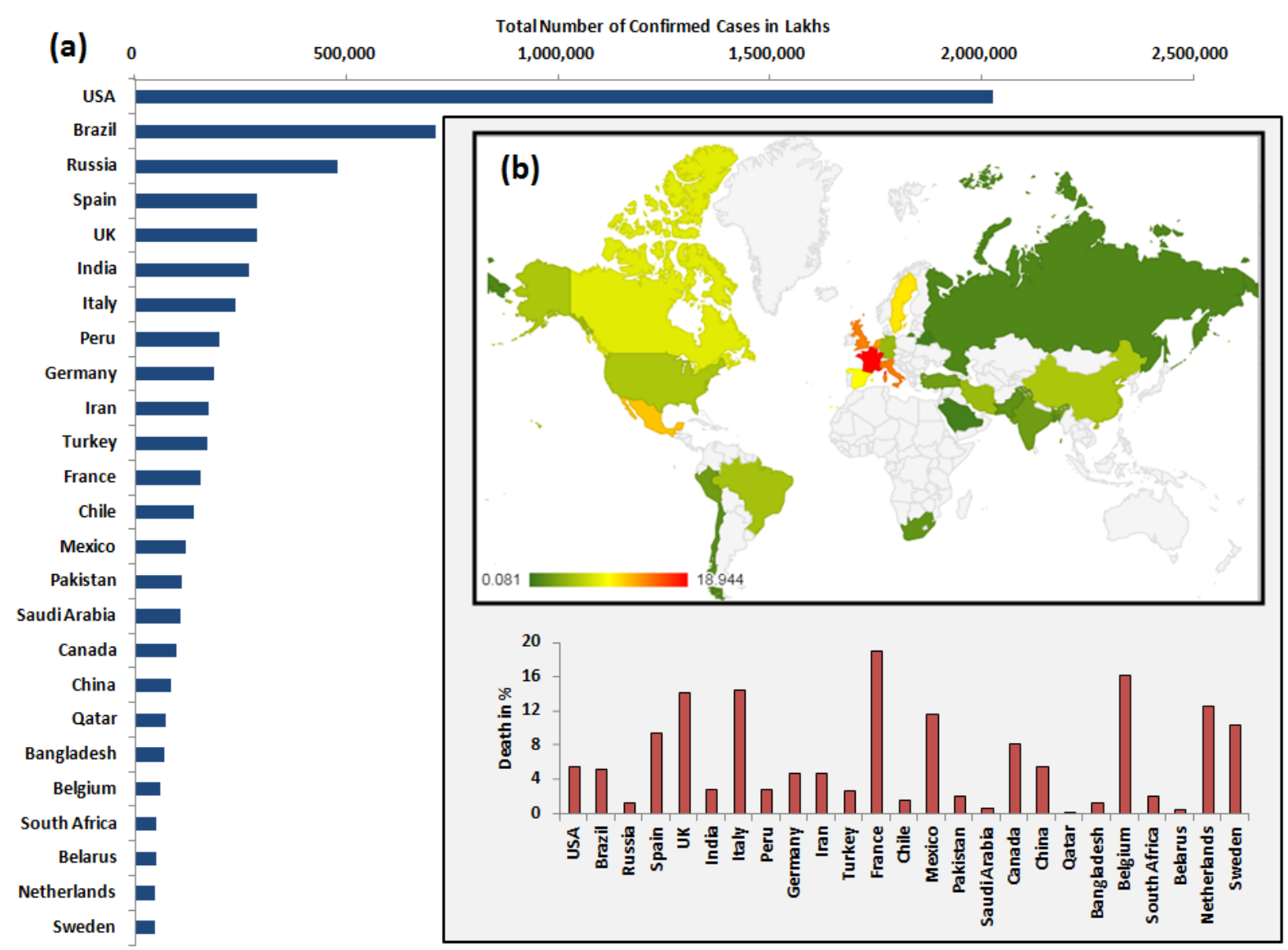

Fig. 1. Representation of world's top 25 worst hit countries by SARS-CoV-2 as of May 15, 2020. (a) Bar diagram showing the total number of cases. (b) World map (upper panel) and bar diagram (lower panel) representing the \% of death in top 25 countries (Worldometer Corona, 2020) 
This link was confirmed by the Chinese Centre for Disease Control and Prevention, which could successfully isolate and identify the SARS-CoV-2 from the environmental samples of Huanan seafood market. Few different strains of coronavirus were previously identified a few months earlier from the same market (Xiong et al., 2020). The bronchoalveolar lavage fluid was first used to isolate SARS-CoV-2 from three patients with clinical symptoms from Wuhan Jinyintan Hospital (Zhu et al., 2020) and the virus was identified after its genome sequencing and evolutionary tree analysis (Zhou et al., 2020). According to the recent classification developed by Coronaviridae Study Group (CSG) of International Committee on Taxonomy of Viruses, there are two subfamilies five genera, 27 subgenera and 39 species which comes under the family of Coronaviridae with suborder, order and realm, Cornidovirineae, Nidovirales and Riboviria respectively (Gorbalenya et al., 2020). The positive sense single stranded RNA, SARSCoV-2 belongs to the genus Betacoronavirus and subgenus Sarbecovirus (Gorbalenya et al., 2020). Genome-wide phylogenetic analysis revealed the sequence similarity between the coronaviruses with the recent SARS-CoV-2. It almost shares $79.5 \%$ similarity with SARS$\mathrm{CoV}$ and $50 \%$ similarity between MERS-CoV (Lu et al., 2020; Zhou et al., 2020; Zhu et al., 2020).

The highest sequence similarity of $94.6 \%$ between the SARS-CoV-2 and SARS-CoV was observed in seven conserved replicase domains of ORF1ab which indicates that SARS-CoV-2 belongs to the Sarbecovirus of $\beta$-CoV's (F. Wu et al., 2020). The genomic size of SARS-CoV2 virion is about $29.9 \mathrm{~kb}$ (Guo et al., 2020). The genomic RNA, along with phosphorylated nucleocapsid, is surrounded by the phospholipid bilayers. Two different spike proteins - the spike glycoprotein trimmer (S) and hemagglutinin-esterase (HE) are embedded in the phospholipid bilayer. The $\mathrm{S}$ protein is present in all coronaviruses, and HE exists in only a few kinds of CoVs. The envelope (E) protein and membrane $(\mathrm{M})$ protein exist along with spike protein (F. Wu et al., 2020).

\section{Evolutionary Insights}

Bats are the known natural hosts for all the coronaviruses discovered until now, which infect humans (Vijaykrishna et al., 2007). During 2002 SARS pandemic, civets were pointed out to be natural suspects of human transmission, but later they were known to be intermediate hosts. A vast reservoir of genetically diverse coronaviruses was identified in Chinese rhinolophid bats in Yunnan Province, China. This led to the conclusion that bats are the natural hosts for many coronaviruses including SARS-CoV-2 which showed high sequence similarity of $96 \%$ with RaTG13 bat coronavirus (Lau et al., 2005; Ge et al., 2013; Corman et al., 2018; F. Wu et al., 2020). It may be either transmitted due to the eating habits of few people or through an intermediate animal host which is in close contact with humans. The SARS-CoV might undergo mutation or recombination in these animal hosts in order to survive and transmit among humans. At whole-genome level, the sequence similarity between SARS-CoV-2 and Pangolin $\mathrm{CoV}$ is $72 \%$ which designates the status of pangolins as intermediate hosts of COVID-19 (Lam et al., 2020).

Further studies on tracking the sequence identity of CoV's between multiple species will help us in better understanding of the disease. The initial genome sequencing from the clinical samples of 10 subjects revealed no variation with $99.98 \%$ sequence similarity ( $\mathrm{Lu}$ et al., 2020; Zhou et al., 2020). The significant change in variation was observed by Tang et al. (2020a) after examining and comparing 103 genomes of SARS-CoV-2. 
He concluded that the SARS-CoV-2 was evolved into $\mathrm{L}$ and $\mathrm{S}$ types due to severe selective pressure. He also highlighted that the $\mathrm{L}$ type might be much aggressive that $\mathrm{S}$ type as it underwent higher selective pressure than $\mathrm{L}$ type (Tang et al., 2020b). The comparative crystal and atomic binding studies on spike protein in complex with the Angiotensin Converting Enzyme 2 (ACE2) receptor revealed that SARS-CoV2 has higher affinity towards ACE2 receptor than SARS-CoV due to key residue. This is one of the important evolutionary steps which support increased pathogenicity in COVID-19 (Lan et al., 2020).

In SARS-CoV-2, a 380 amino acid substitutions was also observed in various proteins when compared to SARS-CoV, but their significance and impact on pathogenesis is still unclear (A. Wu et al., 2020b). He concluded that the SARS-CoV-2 was evolved into $\mathrm{L}$ and $\mathrm{S}$ types due to severe selective pressure. He also highlighted that the $\mathrm{L}$ type might be much aggressive that $S$ type as it underwent higher selective pressure than $L$ type (Tang et al., 2020b). The comparative crystal and atomic binding studies on spike protein in complex with the Angiotensin Converting Enzyme 2 (ACE2) receptor revealed that SARS-CoV2 has higher affinity towards ACE2 receptor than SARS-CoV due to key residue. This is one of the important evolutionary steps which support increased pathogenicity in COVID-19 (Lan et al., 2020). In SARS-CoV-2, a 380 amino acid substitutions was also observed in various proteins when compared to SARS-CoV, but their significance and impact on pathogenesis is still unclear (A. Wu et al., 2020b).

\section{Epidemiology and Statistics}

On December $31^{\text {st }} 2019$, the WHO was informed about the cluster of cases with pneumonia-like symptoms at Wuhan City,
Hubei Province, China. On January $7^{\text {th }} 2020$, Chinese authorities confirmed the new type of coronavirus which they called novel coronavirus. Other pathogens like SARS, MERS, adenoviruses and other influenza viruses were ruled out for causing pneumonialike symptoms in Wuhan citizens. On $12^{\text {th }}$ January, WHO with the National Health Commission indicated that the evident outbreak is associated with exposures in one seafood market in Wuhan. The entire city of Wuhan was quarantined on January $23^{\text {rd }}$, and the lockdown was further extended to other parts of the country and the world. On March $11^{\text {th }}$ 2020, WHO declared COVID-19 as world pandemic but by that time, almost 100 countries with more than 100,000 cases were reported (Fig. 2). Furthermore, as of $9^{\text {th }}$ June 2020, a total of 7,238,307 cases and 409,634 fatalities were reported (WHO, 2020). The percentage of death also varied between top 25 leading countries. It shows a minimum of $0.081 \%$ in Qatar to $18.94 \%$ in France (Worldometer Corona, 2020). This variation observed is governed by various factors like age, sex and other comorbidities a patient exhibit during infection. Other reasons, like the evolution of the virus into a more virulent form, cannot be ruled out (Fig. 1).

Epidemiological investigation revealed that the outbreak started from Wuhan seafood market. The early COVID-19 patients in China had a history of visiting the Wuhan's seafood market and later the transmission was through their respiratory droplets (Neeltje van Doremalen et al., 2020). The SARS-CoV-2 viral proteins were also detected from blood and faeces of the infected subjects (W. Wang et al., 2020), but no significant transmission was identified (Aylward, Bruce (WHO); Liang, 2020). According to the recent study, asymptomatic people can also infect the population (Hoehl et al., 2020). 
This poses a great threat as the asymptomatic carrier might not know that he/she is the carrier of the novel coronavirus but still can infect others. Once a person's immune system comes in contact with the virus, the body starts showing the symptoms within 2 to 14 days after the onset of infection. Children have the majority of the chances of getting asymptomatic infections; the assessed risk percentage for this is almost close to $15.5 \%$.

The average incubation period in adolescent and younger adults is eight days, and $50 \%$ of their family members showed symptoms in 1.4 days after exposure (Liao et al., 2020; D. Wang et al., 2020).

\section{Pathogenesis}

Viral infections which belong to Category $A$ and $B$ of influenza viruses are usually responsible for seasonal epidemics causing lung infections (Boktor \& Hafner, 2020). Flu viruses are declared as one of the potential bioweapons by Journal of Royal Society of Medicine (Madjid et al., 2003). The spread and severity of coronaviruses are dependent on various indirect factors like error susceptible replicase inducing mutations and multiple recombination episodes in the genetic material of virus (Cui et al., 2019). In case of coronavirus, as soon as it enters the host body, the epitope of S-Glucoprotein (spike protein) attaches to the ACE2 receptors of various organs cells, but primarily with epithelial lining of the upper respiratory tract and then it proceeds towards lower respiratory tract (Xiao et al., 2020).

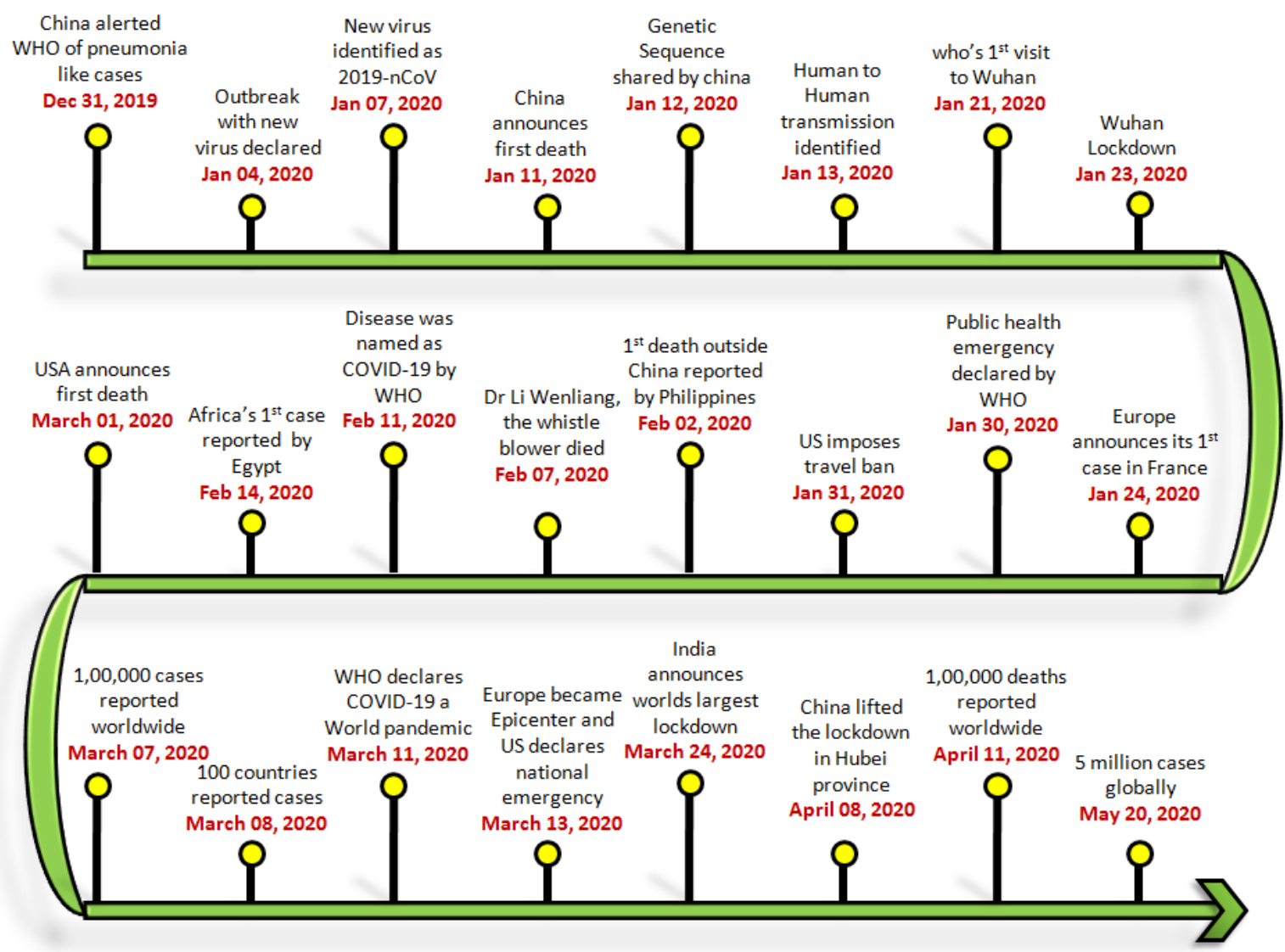

Fig. 2. Timeline showing the most important events occurred in the world from novel coronavirus outbreak in China untill June $09^{\text {th }} 2020$ (Original, 2020) 
The viral spike protein has two subunits; S1 which determines the host selectivity and cellular tropism through receptor binding domain (RBD) and S2, which mediates viral envelop and cell membrane fusion by heptad repeat (HR)1 and HR2 (Xia et al., 2020). Recent studies also showed that the virus enters through CD147, a novel entry point ( $\mathrm{Su}$ et al., 2020). ACE2 receptors are enzymatic receptors (Hamming et al., 2004), which are also reported to be present in cells of various vital body parts like stomach linings, kidneys, lungs, renal tissues, etc. So, the cells which have the ACE 2 receptors are more susceptible to the infection. A recent report also showed the presence of virus in testis, which might affect the fertility of patients in their young age (Fan et al., 2020).

After the attachment, the bound ACE2 receptor will be cleaved by transmembrane protease serine 2 enzyme (TMPRSS2) which facilitates the viral entry into the epithelial cells. The viral genome will be uncoated, and the translation machinery of host synthesizes two polypeptides, ppla and pplab (Guo et al., 2020). They encode replicase and other nonstructural proteins forming replicationtranscription complex which synthesizes subgenomic RNA's encoding viral proteins. The newly synthesized genomic RNA, envelop, and capsid proteins will be assembled, and the virions are released out of the cell via ER and golgi apparatus (Hussain et al., 2005) (Fig. 3). This rapid replication creates an enormous interferon and cytokine storm by the host triggering inflammatory response leading to tissue injury and acute respiratory distress syndrome (ARDS) further driving to coma or sudden death (Tetro, 2020).

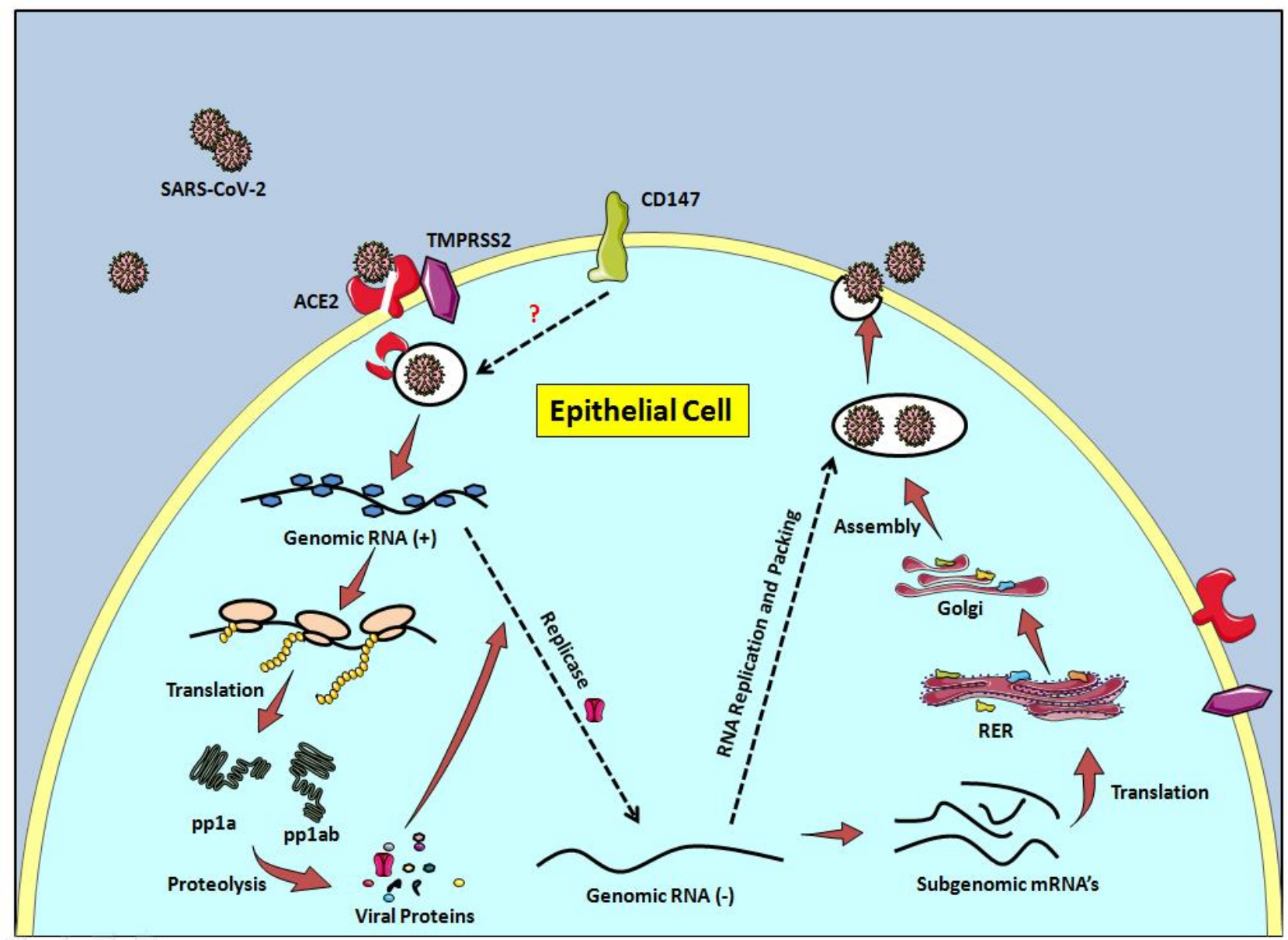

Fig. 3. Graphical representation of life cycle of SARS-CoV-2 in epithelial cells (Original, 2020) 


\section{Symptoms}

SARS CoV infected around 8000 people worldwide and reported to cause 774 deaths (Cherry, 2004). All the cases reported flu-like symptoms, dry cough, and heaviness in breathing. MERS $\mathrm{CoV}$ infection cases were reported in 2012 in Saudi Arabia, and the patients died soon due to respiratory failure (Alraddadi et al., 2016). Novel Coronavirus reported to have much higher efficiency to replicate in the human host with high rate of transmission. It enters the lung cells by crossing the upper respiratory tract and attaches to the ACE2 receptors of host cell using its spike proteins (Tai et al., 2020). Its penetration into the lungs causes pneumonia of unknown etiology. Viruses of this family are known to cause various diseases like enteric, respiratory and neurological illness in different animals as well (Perlman \& Netland, 2009; Chen et al., 2020). The disease spectrum varies from asymptomatic condition to clinical conditions like respiratory system failures, which in severe cases needs ventilators leading to fatalities. The mild symptoms include fever, dry cough and dyspnea and atypical pneumonia (Huang et al., 2020). Usually, the disease initiates with difficulty in breathing and chest heaviness. Though the mortality rates are as low as $2-3 \%$, the death is mostly accountable to the patient's hyper response to the viral invasions driving to sepsis (Gyawali et al., 2019). The chances of sepsis and pneumonia increase with preexisting co-occurring conditions like heart disease, lung infection, cancers and diabetes (Hotchkiss et al., 2016). The foremost reason behind the high risk of a novel coronavirus in these patients is that they already possess a weaker immune system. According to the study on 138 patients of Zhongnan Hospital, Wuhan city, almost $98.6 \%$ showed fever, $69.6 \%$ showed fatigue and $59.4 \%$ were with dry cough. Lymphopenia and higher lactate dehydrogenase levels were also observed in $70.3 \%$ and $39.9 \%$ patients, respectively (Fig. 4) (D. Wang et al., 2020).

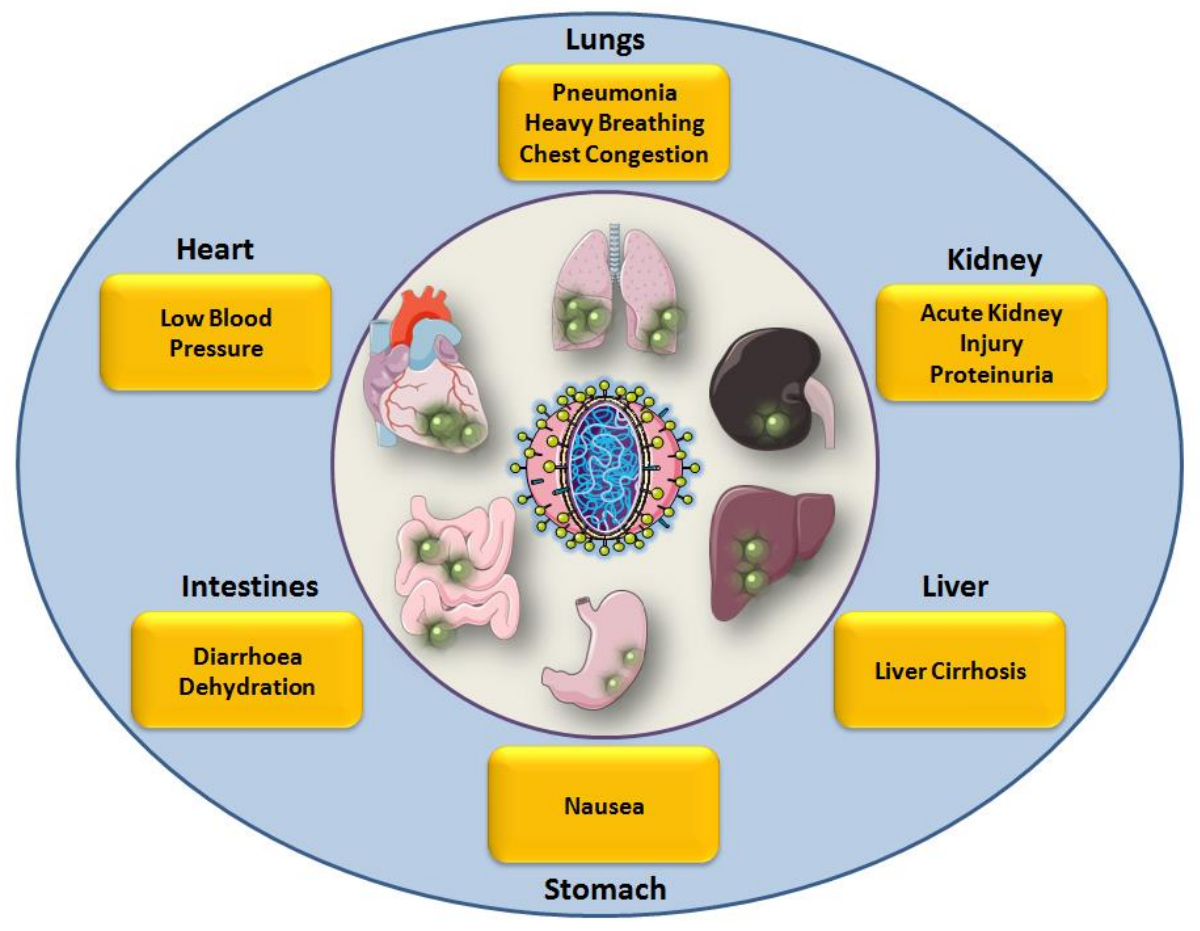

Fig. 4. The pathogenic alterations exhibited by SARS-CoV-2 on various organs and its related symptoms (Original, 2020) 
In a conclusive report of CDC (Centre for Disease Control and Prevention, US) about China, the symptoms were divided into the following ways, i.e. mild disease phase (MDP), severe disease phase (SDP) and critical disease phase (CRP). In MDP, the infected person shows the symptoms associated with fever, dry cough and no pneumonia to mild pneumonia in most of the cases. In many cases, diarrhoea and severe stomach ache are reported as the first signs of virus infection (Pan et al., 2020). In the second phase, SDP, the patients acquire health deteriorating symptoms like dyspnoea, higher respiratory frequency of $\geq 30 / \mathrm{min}$, low blood oxygen saturation of $\leq 93 \%$, reduced $\mathrm{P} / \mathrm{F}$ ratio of $\leq 300 \mathrm{~mm} \mathrm{Hg}$, and lung infiltrates of $>50 \%$ in $48 \mathrm{hrs}$. This occurred in $14 \%$ of the patients admitted in Wuhan hospital by February end. Patients with low immune responses proceed to the third phase (CRP). They undergo respiratory failure, low blood pressure and multiple organ failure due to sepsis/septic shock. This phase was confirmed only in $5 \%$ of the admitted cases ( $\mathrm{Z}$. Wu \& McGoogan, 2020). These patients exhibited a unique pattern of immune deregulation comprising macrophage activation syndrome or depletion of CD4 lymphocytes and NK cells (Evangelos et al., 2020).

Post-mortem samples of heart, lung and liver showed the bilateral diffuse alveolar damage with cellular fibromyxoid exudates. Desquamation or peeling of pneumocytes and hyaline membrane formation indicated ARDS (Acute Respiratory Distress Syndrome). Lung tissues showed pulmonary oedema along with interstitial inflammatory lung infiltrates. Multinucleated syncytial cells with large nuclei indicate viral cytopathic-like changes (Aylward, Bruce (WHO); Liang, 2020).

\section{Diagnosis}

After the analysis and careful observation of the symptoms, it is essential to diagnose the disease accurately for confirmation. After proper identification of symptoms like dry cough, fever, chest heaviness and difficulty in the breathing, the specimen (nasopharyngeal and oropharyngeal swabs) are collected for diagnosis from upper respiratory tract. From lower respiratory tract, expectorated sputum, endotracheal aspirates, bronchotracheal lavage were collected for analysis (Aylward, Bruce (WHO); Liang, 2020).

Chest X-ray and CT imaging were used to examine the extent of pneumonia in the chest region. The chest X-ray helps in understanding the status of interstitial lung disease, presence of lung opacity, the accumulation of liquid in lungs, thickening of the pleural membrane which later leads to calcification of pleural membrane, hilar lymphadenopathy which is observed in some of the patients. Mediastinal strips and the cardiac silhouette are also identified by chest X-ray. CT scan helps in assessing the common findings like ground glass opacity, crazy paving in the right upper lobe of the lung, lateral segment of the middle lobe and lesions in the superior and posteriorbasal segments of the right lower lobe (Albarello et al., 2020). A molecular technique that is widely used for identification of the viral genome in the infected person is RT- PCR. It is not widely appreciated as the test accuracy is greatly dependent on the experience of the lab personnel, sterile lab environment and type and condition of the specimen being tested (Centers for Disease Control and Prevention, 2020). Due to this limitation, the CFDA has approved a few sequencing and nucleic acid testing kits which depend on quantitative fluorescence. This kit found to be much more accurate than RT-PCR but prone to false-negatives. To address this, rapid nucleic acid test papers for detection within a few minutes was developed. Serological assays include ELISA and microneutralization test (Centers for Disease Control and Prevention, 2020), which mainly 
detects the presence of viral protein were also developed (Fig. 5). The other test like colloidal gold solution test, CRISPR/Cas13 System test, which was widely used for ZIKA and DENGUE infections (Myhrvold et al., 2018) also gave a result for Corona viral proteins. However, they are currently for the research and surveillance purpose only.

\section{Therapeutic interventions}

Treatment for many viral diseases is difficult, and presently, there are no specific drugs to treat this COVID-19 pandemic. There are various effortful treatment strategies proposed all over the world. The most popular treatment is with hydroxychloroquine which was under consideration by the USA. Here we summarize potential treatment options for COVID-19 (Fig. 6).

\section{Small Molecules}

Currently, the drug which is widely used in clinical trials and also in clinics is hydroxychloroquine. The exact mode of action of this anti-malarial drug is not yet elucidated in the viral scenario, but through the laboratory studies, it is believed to change the $\mathrm{pH}$ of the host cell surface halting the viral entry.

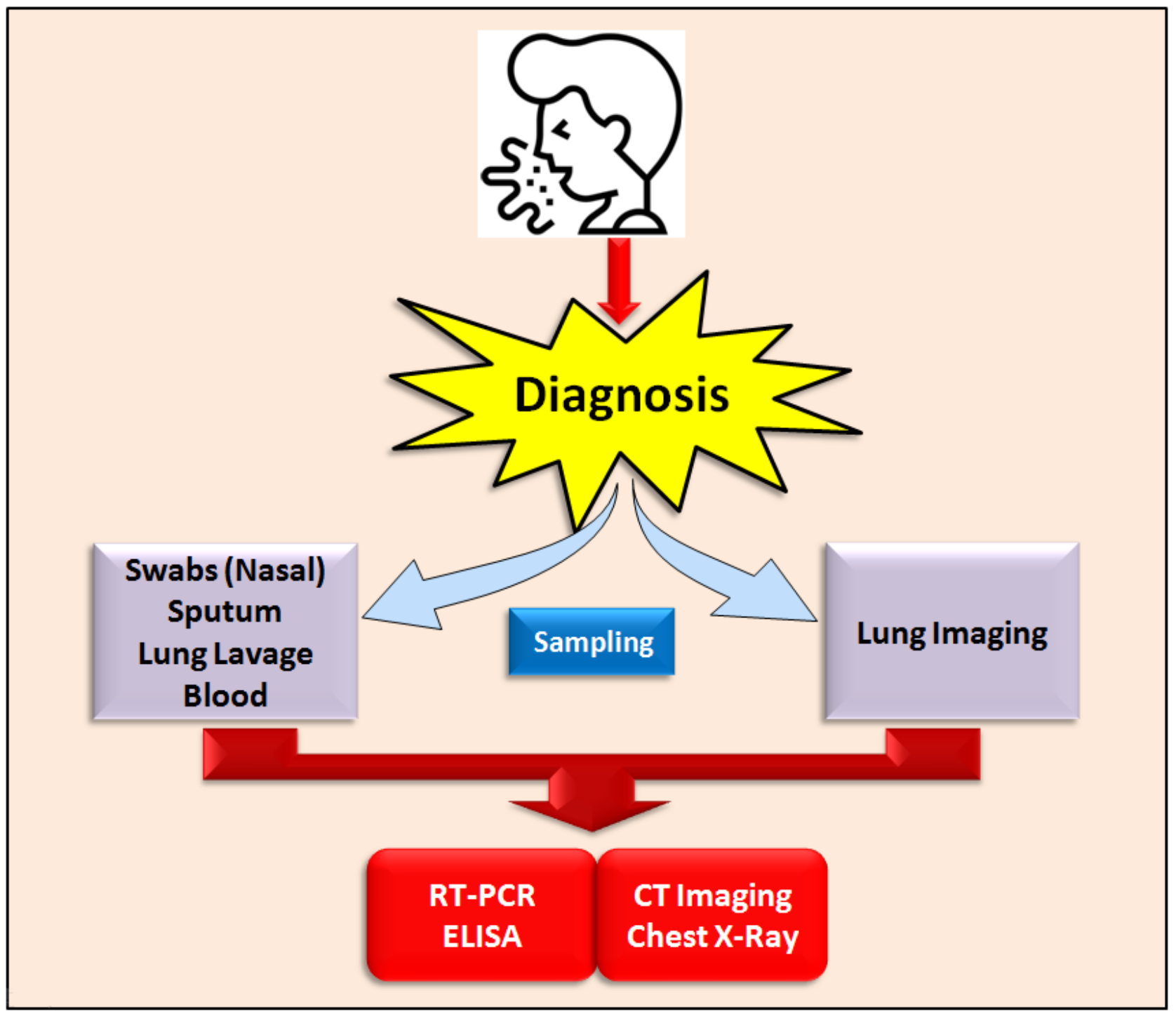

Fig. 5. Representation of current diagnostic techniques used in clinics to detect COVID-19 (Original, 2020) 


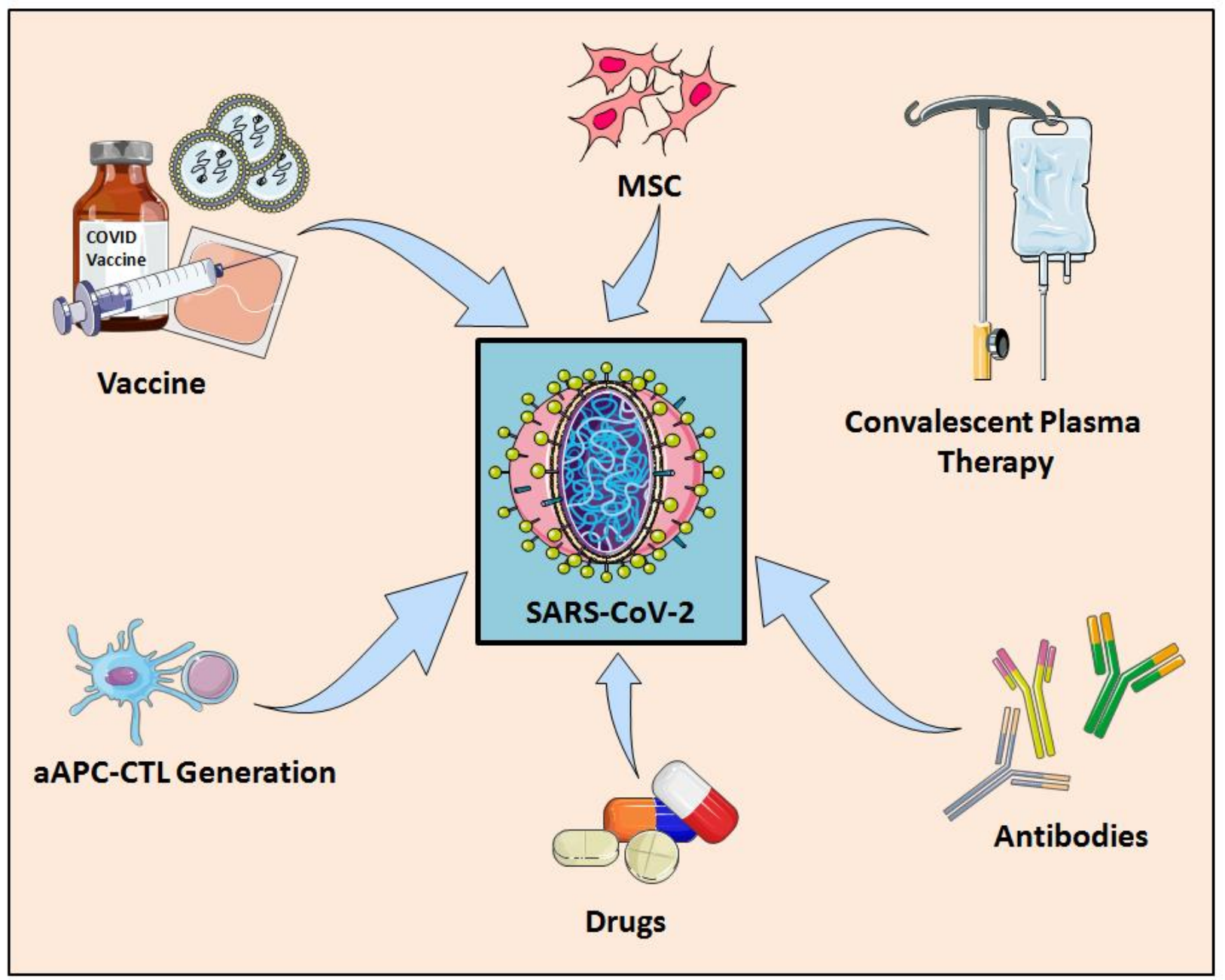

Fig. 6. Graphic representation of various therapeutic intervention methods currently in clinical trials and clinics to treat COVID-19 (Original, 2020)

This is also meant to restriction of viral transcriptomes by inhibiting the nucleic acid replication, thus imparting its antiviral properties (Fox, 1993). Few studies also pointed out its role in controlling cytokine storm in the infected host by its immunomodulatory effect (Yao et al., 2020). Many antiviral compounds which were used during SARS and MERS pandemic were again being considered to treat COVID-19 by many nations across the world. For example, in vivo experiments with remdesiver which has broad spectrum antiviral properties showed its restraining capability on SARS-CoV. It is a nucleotide analogue which inhibits viral RNA polymerases (Grein et al., 2020). Few in vitro studies also showed its antiviral activity in
SARS-CoV-2, leading to its usage as a prime drug to the first COVID-19 patient in the USA (Agostini et al., 2018; Sebastian Hoehl et al., 2020; M. Wang et al., 2020). A further efficacy and safety studies should be carried out for its constant usage. A combination treatment of ritonavir and lopinavir is greatly used in the treatment of HIV, which also proved to be effective in MERS and SARS (Chu et al., 2004; Kim et al., 2016). Furthermore, a clinical trial was already started to check its effect on SARS-CoV-2. Ribavirin was widely used during the SARS outbreak in Hong Kong, which can inhibit SARS-CoV replication in vitro synergistically along with IFN- $\beta$ (Wenzel $\&$ Edmond, 2003; Morgenstern et al., 2005). 
A serious consideration regarding the usage of ribavirin and IFN- $\beta$ combination should be done for the SARS-CoV-2 infection also. Chloroquine interferes with ACE2 receptor of host and thereby blocks the viral entry. In vitro studies also showed its effect on viral replication which stands out it as a potent SARS-CoV-2 inhibitor (Yamamoto et al., 2004; M. Wang et al., 2020). Arbidol and its derivative arbidolmesylate are broad-spectrum antiviral agents which are proved to be effective in inhibiting HIV, SARS-CoV and SARS-CoV-2 in vitro, which entered into clinical trials (Jin et al, 2020). Another vital molecule is Nelfinavir which is a selective HIV protease inhibitor. It also showed potent inhibition of SARS-CoV (Yamamoto et al., 2004), which notifies its therapeutic value in COVID-19. As $\mathrm{S}$ protein binds to ACE2 receptor of host for the viral entry, the blockade of it and downstream signalling helps in viral restriction. ACE2 is involved in Reninangiotensin system (RAS) and so ACE1 and AT1R, RAS inhibitors can be potential therapeutic molecules for treating COVID-19. Another drug, danoprevir, also called as Ganovo acts as HCV protease inhibitor. This drug is given in combination with ritonavir $\begin{array}{lllll}\text { which acts as a Cytochrome } & \mathrm{P} 450 & 3 \mathrm{~A} 4\end{array}$ (CYP3A4) inhibitor, which in turn increases the plasma concentration of Ganovo. The principal reason behind using this combination of the drug is that the chymotrypsin-like protease of SARS CoV-2 exhibits similarities with HCV and HIV proteases thereby following the similar inhibitory trend. This combination is given to the patient in the presence or absence of interferon nebulisation (Hongyi et al., 2020). When the drug favipiravir, a new RNA-dependent RNA polymerase $(\mathrm{RdRp})$ inhibitor is present in the infected host, it gets converted into active phosphoribosyl molecule. It is recognized as a substrate by viral RNA polymerase, hence inhibiting RNA Polymerase activity (Furuta et al., 2017). Repurposing of few viral RNA synthesis inhibitors like emtricitabine, tenofovir, disoproxil were also under consideration due to their known Absorption, Distribution, Metabolism, Excretion and Toxicity (ADMET) processes (Harrison, 2020). Another drug which is under the trials is thiolanox, given in high doses to treat patients with ARDS. The controlled trials are being conducted in both paediatric and adult patients to improve their lung oxygen and pulmonary artery pressure. Another fascinating drug, DAS181 (Fludase) is known to cleave the host cell receptors (sialic acid) which support for viral entry. In-vitro studies show immense success against human and Avian flu viruses (Triana-Baltzer et al., 2009). Anakinra (IL-1 inhibitor), in combination with Siltuximab (Anti-IL6 antibody), reduce the cytokine storm syndrome, which occurs in corona patients due to hyperactivity of antibodies (Mehta et al., 2020). Sildenafil, a common Viagra drug is under clinical trials for COVID-19 to open a tiny blood vessel that helps in drawing blood and oxygen in the lungs, thus can get better in respiratory distress (Healy, 2020). Fingolimod, when phosphorylated forms fingolimodphosphate, which is similar to naturally occurring sphingosine 1-phosphate. It has both anti-inflammatory and anticancerous properties (Lankadasari et al., 2018). It is also under clinical trials for COVID-patients (Table 1).

\section{Convalescent plasma therapy:}

Another way of treating the COVID-19 is by using the convalescent serum or plasma. The serum is collected from the patients who recovered from the infection and after careful scrutiny for any traces of the virus; the antibodies are extracted and injected into the current patients of the novel coronavirus. 
Even though it is still on the trial run but similar attempts was earlier made in the outbreak of 2009-2010 H1N1 influenza, 2013 West African Ebola epidemic (Casadevall \& Pirofski, 2020). Earlier in 2003, the utility of convalescent serum was tested in Hongkong on 80 SARS patients who were proved to be the most effective than any other medication (Cheng et al., 2005). Recently many clinics started trying this therapy when a COVID-19 patient is critically ill. So, there is a tremendous hope that even this time, the use of the convalescent may stand out.

\section{Monoclonal antibodies}

The monoclonal antibodies (mAbs) are efficient by blocking syncytia formation during SARS-CoV infection (J. Duan et al., 2005). Tocilizumab is an IL-6 antagonist, used in rheumatoid arthritis and it is in clinical trials along with DAS181 to inhibit the SARS-CoV2 infection. Sarilumab and siltuximab also target the IL-6 pathway by binding and blocking the IL-6 receptor. Scientists are suggesting that it might play an essential role in severe respiratory infections and in combating cytokine release storm (Hodgson, 2020). The antibody, bevacizumab, is currently being used in various cancer treatments. It is a vascular endothelial growth factor (VEGF) blocker which is being studied in COVID-19 patients to deal with the conditions like hypoxia. Interferons are the primary immune regulators during viral infection. The hypersecretion during the viral attack hyperactivates immune system resulting in tissue injury. Emapalumab, an anti-interferon-gamma antibody is used in hemophagocytic lymphohistiocytosis is also in clinical trials with anakinra to restrain the organ failure due to hyperimmune activation (Lounder et al., 2019). The spike protein of SARS-CoV-2 also binds with CD147 to invade the host cell. Usage of meplazumab, an antiCD147 antibody in the treatment of COVID-19 blocks the viral entry into the cells (Lythgoe \& Middleton, 2020) (Table 1).

\section{Vaccine}

The most effective way to completely eradicate the virus infection is through immunizing people by vaccination. Presently, a race in finding the novel coronavirus vaccine was initiated by many nations. Attention was drawn towards the Bacille Calmette-Guérin vaccine (BCG vaccine) as it presented a clear correlation between the severities of COVID19 in the BCG vaccinated countries. It is under clinical trials presuming its role in activating immune system during SARS-CoV-2 infection. The usage of messenger RNA (mRNA) molecules to induce their transcription after their delivery into the host cell is also in careful consideration. A clinical trial was initiated already by exploiting the synthetic viral spike protein mRNA (mRNA-1273) encapsulated with nanoliposomes for its safe delivery (Mishra \& Carnahan, 2020). Various targets like $S$ protein-RBD structure, adenoviral vector-mediated and epitope-based vaccines are proposed and under clinical trials (Abdelmageed et al., 2020; Xie et al., 2020) (Table 2).

\section{MSC Therapy}

Mesenchymal stem cells (MSC) can be easily extracted from various sources like UCMs (Umbilical Cord Matrix) cells, adipose tissues and bone marrow. After injecting the MSC's into the patient, they reach the damaged tissue and initiate the repair and regeneration. It has anti-inflammatory and immunomodulatory responses and also helps in immune response regulation towards the infected cell by antigen (Peroni \& Borjesson, 2011). This technique is under careful consideration in COVID-19 patients, as most of them show lung injury (Table 2). 


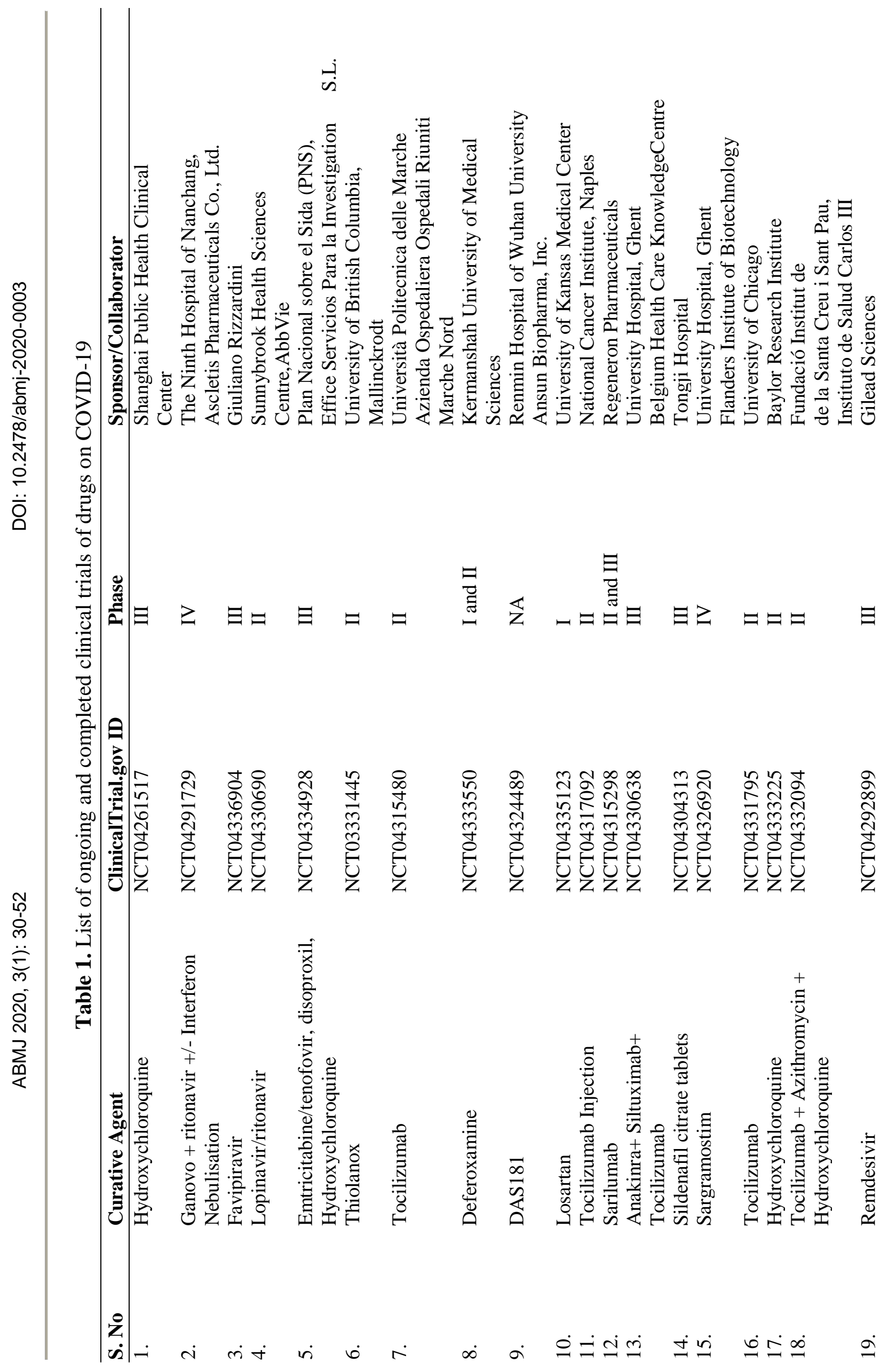




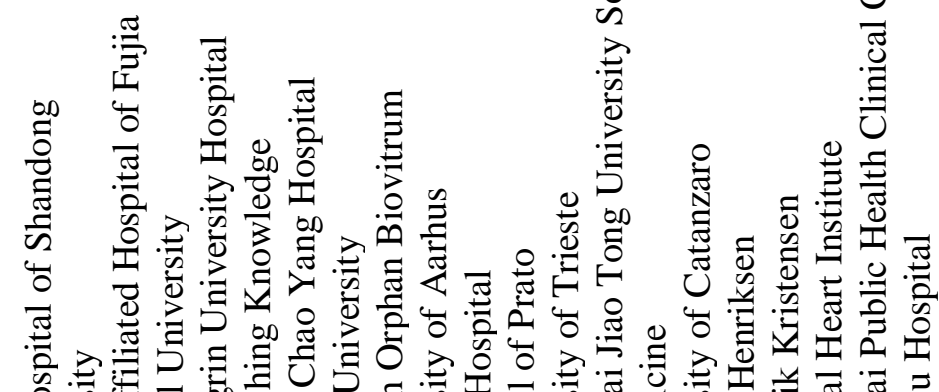

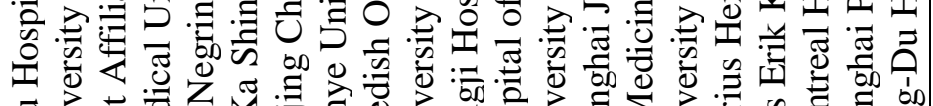

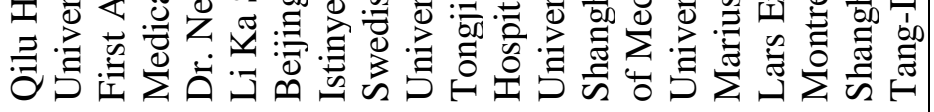

$\overleftrightarrow{z}$ ৫

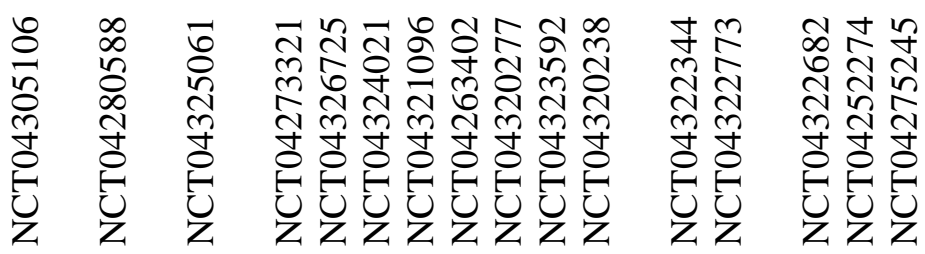

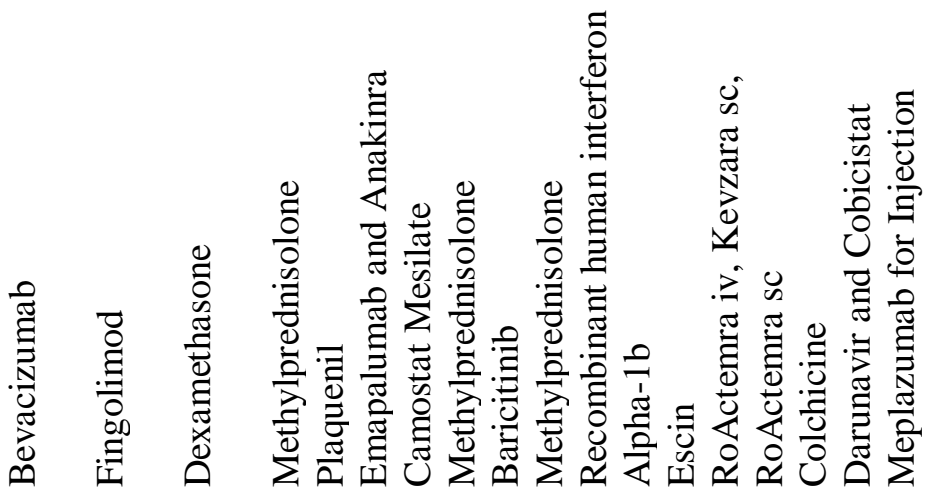

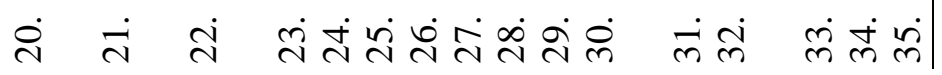




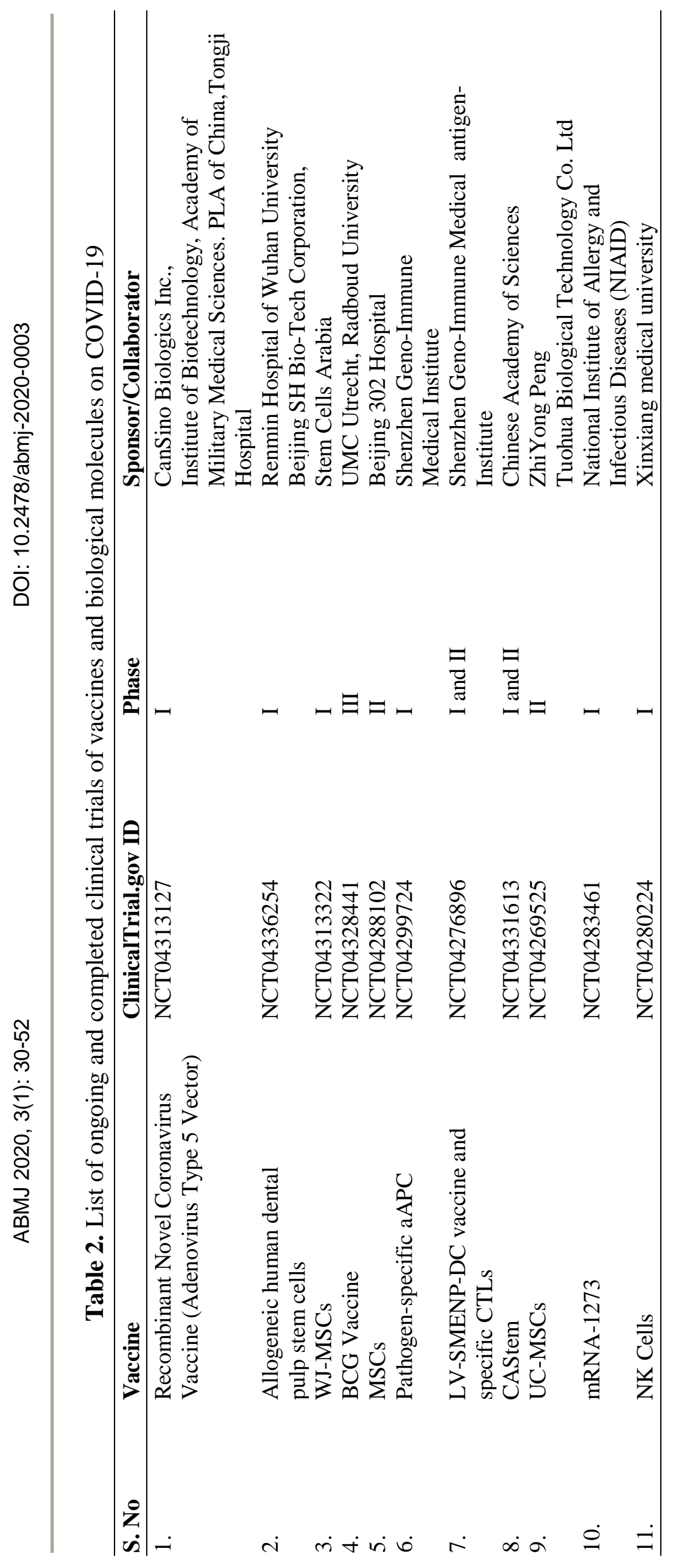




\section{aAPC therapy}

Re-educating immune cells to the viral proteins before the infection is one the method being tested under clinical trials. In this process, the critical and conserved viral genes like protease and structural genes will be engineered as minigenes. They will be transfected into antigen-presenting cells (APC) such as dendritic cells to generate artificial APCs. They will be used to activate cytotoxic $\mathrm{T}$ cells in vitro or will be directly injected into the patient after inactivating their proliferative capacity (Table 2 ).

\section{Conclusions}

"The word pandemic must be used very carefully as it creates the fear amongst the populations of the world"- A statement by WHO when SARS-CoV-2 was declared as a pandemic. Today, with all the highly sophisticated scientific knowledge, we are stuck dealing with an novel coronavirus, which invaded almost all the parts of the world. The initial screenings on bronchoalveolar lavage of three infected patients identified it as SARSCoV-2, which was closely related to its $\beta$ subfamily members, i.e. SARS-CoV and MERS-CoV. They are known to exhibit a similar kind of response to the vital organs of the host body. Chinese government initially managed to conceal its zoonotic nature from the rest of the world, but in a few days, it infected a large number of populations in Wuhan, China. Sooner, due to migration of the people including asymptomatic carriers, it reached other countries, triggering a pandemic. On further investigation, scientists suggested that the transmission is through respiratory droplets of the infected subjects.

The role of the immune system in COVID19 is inevitable. The stronger the immune system, the quicker the patient heals, but, if a person is suffering from any preoccupied disease or smoking, the infection might complicate. The patient might suffer from a sudden lowering of blood pressure, ARDS and in some cases causing diarrhoea like conditions. The genetic drift promotes the evolution of the virus and tracking the viral strains by genome sequencing in all counties help us in understanding the progression and severity of the disease. Presently, the confirmation of the virus was done using RTPCR and CT scan of lungs which are mostly unavailable in rural parts of the developing and underdeveloped nations. Multiple ongoing research and development projects should be encouraged at the lab scale to come up with diagnostic tools to detect the disease much earlier, cheaper and accurate. Usually, chest Xray facility is available rurally, and instant results can be obtained in a short span, but manual analysis by radiologists creates ambiguity. The exploitation of artificial intelligence and machine learning for robust analysis of X-ray data should be coded and made available free to achieve precise results (Mei et al., 2020). If this is achieved, a screening program should be initiated by the government from urban to local community level to test all the citizens and separate those who show symptoms.

Currently, as there is no specific treatment for COVID-19, the first line of treatment is to quarantine the patient. Various drugs like hydroxychloroquine and monoclonal antibodies which halt the viral activity are on clinical trials. A deep understanding of the viral pathogenesis helps us in discovering new pathways which can be targeted using drug repurposing should be encouraged. A balanced promotion of basic research to understand the virus along with the translational work is necessary at this critical time to combat the disease. 
Ultimately, transparency in reporting cases, self-hygiene and social distancing are crucial in controlling COVID-19 as per WHO guidelines.

\section{Conflict of Interest}

The research was conducted in the absence of any commercial or financial relationships. The authors declare no competing interest.

\section{Acknowledgments}

We wish to thank Dr. Usha MS, Dr Shalini U Rao, Dr Harikumar KB, Ms Gayathri G and Ms Vyomika for their support.

\section{References}

1. Abdelmageed MI, Abdelmoneim $\mathrm{AH}$, Mustafa MI, Elfadol NM, Murshed NS, Shantier SW, Makhawi AM (2020) Design of multi epitope-based peptide vaccine against $\mathrm{E}$ protein of human 2019-nCoV: An immunoinformatics approach. BioRxiv 2020.02.04.934232. doi: 10.1101/2020.02.04.934232

2. Agostini ML, Andres EL, Sims AC, Graham RL, Sheahan TP, Lu X, Smith EC, Case JB, Feng JY, Jordan R, Ray AS, Cihlar T, Siegel D, Mackman RL, Clarke MO, Baric RS, Denison MR (2018) Coronavirus susceptibility to the antiviral remdesivir (GS-5734) is mediated by the viral polymerase and the proofreading exoribonuclease. MBio 9:e00221-18. doi: $10.1128 / \mathrm{mBio} .00221-18$

3. Albarello F, Pianura E, Di SF, Cristofaro M, Petrone A, Marchioni L, Palazzolo C, Schininà V, Nicastri E, Petrosillo N, Campioni P, Eskild P, Zumla A, Ippolito G, Abbonizio MA, Agrati C, Amadei G, Amendola A, Antonini M, Barbaro R, Bartolini B, Benigni M, Bevilacqua $\mathrm{N}$, Bordi L, Bordoni V, Branca M, Capobianchi MR, Caporale C, Caravella I,
Carletti F, Castilletti C, Chiappini R, Ciaralli C, Colavita F, Corpolongo A, Curiale S, D'Abramo A, Dantimi C, Angelis AD, Angelis GD, Lorenzo RD, Stefano FD, Ferraro F, Fiorentini L, Frustaci A, Gallì P, Garotto G, Giancola ML, Giansante F, Giombini E, Greci MC, Lalle E, Lanini S, Lapa D, Lepore L, Lucia A, Lufrani F, Macchione M, Marani A, Mariano A, Marini MC, Maritti M, Matusali G, Meschi S, Montaldo FMC, Murachelli S, Noto R, Pallini E, Passeri V, Pelliccioni F, Petrecchia A, Pisciotta M, Pittalis S, Proietti C, Puro V, Rinonapoli G, Rueca M, Sacchi A, Sanasi F, Santagata C, Scarcia S, Scognamiglio P, Scorzolini L, Stazi G, Vaia F, Vairo F, Valli MB (2020) 2019-novel Coronavirus severe adult respiratory distress syndrome in two cases in Italy: An uncommon radiological presentation. Int J Infect Dis 93:192-197. doi: 10.1016/j.ijid.2020.02.043.

4. Alraddadi BM, Watson JT, Almarashi A, Abedi GR, Turkistani A, Sadran M, Housa A, Almazro MA, Alraihan N, Banjar A, Albalawi E, Alhindi H, Choudhry AJ, Meiman JG, Paczkowski M, Curns A, Mounts A, Feikin DR, Marano N, Swerdlow DL, Gerber SI, Hajjeh R, Madani TA (2016) Risk factors for primary middle east respiratory syndrome coronavirus illness in humans, Saudi Arabia, 2014. Emerg Infect Dis 22:49-55. doi: 10.3201/eid2201.151340

5. Aylward, Bruce (WHO), Liang W (PRC) (2020) Report of the WHO-China Joint Mission on Coronavirus Disease 2019 (COVID-19). In- The WHO-China Joint Mission on Coronavirus Disease 2019, 2019(February):16-24. https://www.who.int/docs/defaultsource/coronaviruse/who-china-jointmission-on-covid-19-final-report.pdf. Accessed 05 April 2020 
6. Boktor SW, Hafner JW (2020) Influenza. In: StatPearls. Treasure Island (FL). StatPearls Publishing. PMID: 29083802

7. Casadevall A, Pirofski L (2020) The convalescent sera option for containing COVID-19. J Clin Invest 130:1545-1548. doi: $10.1172 /$ jci138003

8. Centers for Disease Control and Prevention (2020) CDC Laboratory Testing for Middle East Respiratory Syndrome Coronavirus (MERS-CoV) Serology Tests. http://www.cdc.gov/coronavirus/mers/lab/l ab-testing.html. Accessed 05 April 2020

9. Chen Y, Liu Q, Guo D (2020) Emerging coronaviruses: Genome structure, replication, and pathogenesis. J Med Virol 92:418-423. doi: 10.1002/jmv.25681

10. Cheng Y, Wong R, Soo YOY, Wong WS, Lee $\mathrm{CK}, \mathrm{Ng}$ MHL, Chan P, Wong KC, Leung CB, Cheng G (2005) Use of convalescent plasma therapy in SARS patients in Hong Kong. Eur $\mathrm{J}$ Clin Microbiol Infect Dis 24:44-46. doi: 10.1007/s10096-004-1271-9

11. Cherry JD (2004) The chronology of the 2002-2003 SARS mini pandemic. Paediatr Respir Rev 5:262-269. doi: 10.1016/j.prrv.2004.07.009

12. Chu CM, Cheng VCC, Hung IFN, Wong MML, Chan KH, Chan KS, Kao RYT, Poon LLM, Wong CLP, Guan Y, Peiris JS M, Yuen KY (2004) Role of lopinavir/ritonavir in the treatment of SARS: Initial virological and clinical findings. Thorax 59:252-256. doi: 10.1136/thorax.2003.012658

13. Corman VM, Muth D, Niemeyer D, Drosten C (2018) Hosts and Sources of Endemic Human Coronaviruses. Adv Virus Res 100:163-188.

doi: 10.1016/bs.aivir.2018.01.001

14. Sobi (2020) Sobi ' s Anakinra \& Emapalumab Requested for Use in Targeted Clinical Study in Italy to Address
Severe COVID-19 Cases. In:

TrialSiteNews.

https://www.trialsitenews.com/sobis-

anakinra-emapalumab-requested-for-use-

in-targeted-clinical-study-in-italy-to-

address-severe-covid-19-cases/Accessed 05 April 2020.

15. Cui J, Li F, Shi ZL (2019) Origin and evolution of pathogenic coronaviruses. Nat Rev Microbiol 17:181-192. doi: 10.1038/s41579-018-0118-9

16. Jin $\mathrm{Y}$, Yang $\mathrm{H}$, Ji $\mathrm{W}, \mathrm{Wu} \mathrm{W}$, Chen $\mathrm{S}$, Zhang W, Duan G (2020) Virology, Epidemiology, Pathogenesis, and Control of COVID-19. Viruses 12:372. doi: 10.3390/v12040372

17. Duan J, Yan X, Guo X, Cao W, Han W, Qi C, Feng J, Yang D, Gao G, Jin G (2005) A human SARS-CoV neutralizing antibody against epitope on S2 protein. Biochem Biophys Res Commun 333:186-193. doi: 10.1016/j.bbrc.2005.05.089

18. Giamarellos-Bourboulis EJ, Netea MG, Rovina N, Akinosoglou K, Antoniadou A, Antonakos N, Damoraki G, Gkavogianni T, Adami ME, Katsaounou P, Ntaganou M (2020) Complex Immune Dysregulation in COVID-19 Patients with Severe Respiratory Failure. Cell Host Microbe 27:992-1000.e3. doi: 10.1016/j.chom.2020.04.009

19. Fan C, Li K, Ding Y, Lu WL, Wang J (2020) ACE2 Expression in Kidney and Testis May Cause Kidney and Testis Damage After 2019-nCoV Infection. MedRxiv 2020.02.12.20022418. doi: 10.1101/2020.02.12.20022418

20. Fox RI (1993) Mechanism of action of hydroxychloroquine as an antirheumatic drug. Semin Arthritis Rheu 23:82-91. doi: 10.1016/S0049-0172(10)80012-5

21. Furuta Y, Komeno T, Nakamura T (2017) Favipiravir (T-705), a broad spectrum inhibitor of viral RNA polymerase. Proc 
Jpn Acad, Ser B 93:449-463. https://doi.org/10.2183/pjab.93.027

22. Ge XY, Li JL, Yang XL, Chmura AA, Zhu G, Epstein JH, Mazet JK, Hu B, Zhang W, Peng C, Zhang YJ, Luo CM, Tan B, Wang $\mathrm{N}$, Zhu Y, Crameri G, Zhang SY, Wang L F, Daszak P, Shi ZL (2013) Isolation and characterization of a bat SARS-like coronavirus that uses the ACE2 receptor. Nature 503:535-538.

doi: 10.1038/nature12711

23. Gorbalenya AE, Baker SC, Baric RS, de Groot RJ, Drosten C, Gulyaeva AA, Haagmans BL, Lauber C, Leontovich AM, Neuman BW, Penzar D, Perlman S, Poon LM, Samborskiy DV, Sidorov IA, Sola I, Ziebuhr J (2020) The species Severe acute respiratory syndrome-related coronavirus: classifying 2019-nCoV and naming it SARS-CoV-2. Nat Microbiol 5:536-544. doi: 10.1038/s41564-020-0695-z

24. Grein J, Ohmagari N, Shin D, Diaz G, Asperges E, Castagna A, Feldt T, Green G, Green ML, Lescure FX, Nicastri E, Oda R, Yo K, Quiros RE, Studemeister A, Redinski J, Ahmed S, Bernett J, Chelliah D, Chen D, Chihara S, Cohen SH, Cunningham J, D'Arminio MA, Ismail S, Kato H, Lapadula G, L'Her E, Maeno T, Majumder S, Massari M, Mora RM, Mutoh Y, Nguyen D, Verweij E, Zoufaly A, Osinusi AO, DeZure A, Zhao Y, Zhong L, Chokkalingam A, Elboudwarej E, Telep L, Timbs L, Henne I, Sellers S, Cao H, Tan SK, Winterbourne L, Desai P, Mera R, Gaggar A, Myers RP, Brainard DM, Childs R, Flanigan T (2020) Compassionate Use of Remdesivir for Patients with Severe Covid-19. N Engl J Med 382:2327-2336. doi: 10.1056/NEJMoa2007016

25. Guo YR, Cao QD, Hong ZS, Tan YY, Chen SD, Jin HJ, Tan KS, Wang DY, Yan Y (2020) The origin, transmission and clinical therapies on coronavirus disease
2019 (COVID-19) outbreak - an update on the status. Military Med Res 7:11. doi: 10.1186/s40779-020-00240-0

26. Gyawali B, Ramakrishna K, Dhamoon AS (2019) Sepsis: The evolution in definition, pathophysiology, and management. SAGE Open Med 7:1-13 doi: $10.1177 / 2050312119835043$

27. Hamming I, Timens W, Bulthuis MLC, Lely AT, Navis GJ, Van GH (2004) Tissue distribution of ACE2 protein, the functional receptor for SARS coronavirus. A first step in understanding SARS pathogenesis. J Pathol 203:631-637.

doi: $10.1002 /$ path. 1570

28. Harrison C (2020) Coronavirus puts drug repurposing on the fast track. Nat Biotechnol 38:379-381. doi: 10.1038/d41587-020-00003-1

29. Healy M (2020) How a discovery that brought us Viagra could help those battling the coronavirus. In: Bangor Daily News, LA.

https://www.healthleadersmedia.com/innov ation/how-discovery-brought-us-viagracould-help-those-battling-coronavirus.

Accessed 06 April 2020

30. Hodgson J (2020) The pandemic pipeline. Nat Biotechnol 38:523-532. doi: 10.1038/d41587-020-00005-Z

31. Hoehl S, Rabenau H, Berger A, Kortenbusch M, Cinatl J, Bojkova D, Behrens P, Böddinghaus B, Götsch U, Naujoks F, Neumann P, Schork J, TiarksJungk P, Walczok A, Eickmann M, Vehreschild M, Kann G, Wolf T, Gottschalk R, Ciesek S (2020) Evidence of SARS-CoV-2 Infection in Returning Travelers from Wuhan, China. N Engl J Med 382:1278-1280. doi: 10.1056/NEJMc2001899

32. Hongyi C, Zhicheng Z, Li W, Zhihua H, Fanghua G, Xiaodong L, Yahong C, Jinzi JW (2020) First Clinical Study Using HCV 
Protease Inhibitor Danoprevir to Treat Naïve and Experienced COVID-19 Patients Hongyi. MedRxiv 2020.03.22.20034041. doi: $10.1101 / 2020.03 .22 .20034041$

33. Hotchkiss RS, Moldawer LL, Opal SM, Reinhart K, Turnbull IR, Vincent JL (2016) Sepsis and septic shock. Nat Rev Dis Primers 2:1-21. doi: 10.1038/nrdp.2016.45

34. Huang C, Wang Y, Li X, Ren L, Zhao J, $\mathrm{Hu}$ Y, Zhang L, Fan G, Xu J, Gu X, Cheng Z, Yu T, Xia J, Wei Y, Wu W, Xie X, Yin W, Li H, Liu M, Xiao Y, Gao H, Guo L, Xie J, Wang G, Jiang R, Gao Z, Jin Q, Wang J, Cao B (2020) Clinical features of patients infected with 2019 novel coronavirus in Wuhan, China. Lancet 395:497-506. doi: 10.1016/S01406736(20)30183-5

35. Hussain S, Pan J, Chen Y, Yang Y, Xu J, Peng Y, Wu Y, Li Z, Zhu Y, Tien P, Guo D (2005) Identification of Novel Subgenomic RNAs and Noncanonical Transcription Initiation Signals of Severe Acute Respiratory Syndrome Coronavirus. J Virol 79:5288-5295. doi: 10.1128/jvi.79.9.52885295.2005

36. Kim UJ, Won EJ, Kee SJ, Jung SI, Jang HC (2016) Combination therapy with lopinavir/ritonavir, ribavirin and interferona for Middle East respiratory syndrome. Antivir Ther 2:455-459. doi: 10.3851/IMP3002

37. Lam TTY, Shum MHH, Zhu HC, Tong YG, Ni XB, Liao YS, Wei W, Cheung WYM, Li WJ, Li LF, Leung GM, Holmes EC, Hu YL, Guan Y (2020) Identifying SARS-CoV-2 related coronaviruses in Malayan pangolins. Nature. 1-4. doi: 10.1038/s41586-020-2169-0

38. Lan J, Ge J, Yu J, Shan S, Zhou H, Fan S, Zhang Q, Shi X (2020) Structure of the SARS-CoV-2 spike receptor- binding domain bound to the ACE2 receptor. Nature 581:215-220. doi: 10.1038/s41586-
020-2180-5

39. Lankadasari MB, Aparna JS, Mohammed S, James S, Aoki K, Binu VS, Nair S, Harikumar KB (2018) Targeting S1PR1/STAT3 loop abrogates desmoplasia and chemosensitizes pancreatic cancer to gemcitabine. Theranostics 8:3824-3840. doi: 10.7150/thno. 25308

40. Lau SKP, Woo PCY, Li KSM, Huang Y, Tsoi HW, Wong BHL, Wong SSY, Leung SY, Chan KH, Yuen KY (2005) Severe acute respiratory syndrome coronaviruslike virus in Chinese horseshoe bats. Proc Natl Acad Sci USA 102:14040-14045. doi: 10.1073/pnas.0506735102

41. Liao J, Fan S, Chen J, Wu J, Xu S, Guo Y, Li C, Zhang X, Wu C, Mou H, Song C, Li F, Wu G, Zhang J, Guo L, Liu H, Lv J, Xu L, Lang C (2020) Epidemiological and clinical characteristics of COVID-19 in adolescents and young adults. MedRxiv 2020.03.10.20032136.

doi: 10.1101/2020.03.10.20032136

42. Lounder DT, Bin Q, De MC, Jordan MB (2019) Treatment of refractory hemophagocytic lymphohistiocytosis with emapalumab despite severe concurrent infections. Blood Adv 3:47-50. doi: 10.1182/bloodadvances.2018025858

43. Lu R, Zhao X, Li J, Niu P, Yang B, Wu H, Wang W, Song H, Huang B, Zhu N, Bi Y, Ma X, Zhan F, Wang L, Hu T, Zhou H, Hu Z, Zhou W, Zhao L, Chen J, Meng Y, Wang J, Lin Y, Yuan J, Xie Z, Ma J, Liu WJ, Wang D, Xu W, Holmes EC, Gao GF, Wu G, Chen W, Shi W, Tan W (2020) Genomic characterisation and epidemiology of 2019 novel coronavirus: implications for virus origins and receptor binding. Lancet 395:565-574. doi: 10.1016/S0140-6736(20)30251-8

44. Lythgoe MP, Middleton P (2020) Ongoing Clinical Trials for the Management of the COVID-19 Pandemic. Trends in 
Pharmacological Sci 41:363-382. doi: 10.1016/j.tips.2020.03.006

45. Madjid M, Lillibridge S, Mirhaji P, Casscells W (2020) Influenza as a bioweapon. J R Soc Med 96:345-346. doi: 10.1177/014107680309600709

46. Mehta P, McAuley DF, Brown M, Sanchez E, Tattersall RS, Manson JJ (2020) COVID-19: consider cytokine storm syndromes and immunosuppression. The Lancet 395:1033-1034.

doi: 10.1016/S0140-6736(20)30628-0

47. Mei X, Lee HC, Diao KY, Huang M, Lin B, Liu C, Xie Z, Ma Y, Robson PM, Chung M, Bernheim A, Mani V, Calcagno C, Li K, Li S, Shan H, Lv J, Zhao T, Xia J, Long Q, Steinberger S, Jacobi A, Deyer T, Luksza M, Liu F, Little BP, Fayad ZA, Yang Y (2020) Artificial intelligenceenabled rapid diagnosis of patients with COVID-19. Nat Med 1-5. doi: 10.1038/s41591-020-0931-3

48. Mishra S, Carnahan R (2020) Coronavirus : A new type of vaccine using RNA could help defeat COVID-19. 2, 1-5, Australia. In: The Conversation Blog. https://theconversation.com/coronavirus-anew-type-of-vaccine-using-rna-could-helpdefeat-covid-19-133217. Accessed 06 May 2020

49. Morgenstern B, Michaelis M, Baer PC, Doerr HW, Cinatl J (2005) Ribavirin and interferon- $\beta$ synergistically inhibit SARSassociated coronavirus replication in animal and human cell lines. Biochem Bioph Res Co 326:905-908.

doi: 10.1016/j.bbrc.2004.11.128

50. Myhrvold C, Freije CA, Gootenberg JS, Abudayyeh OO, Metsky HC, Durbin AF, Kellner MJ, Tan AL, Paul LM, Parham LA, Garcia KF, Barnes KG, Chak B, Mondini A, Nogueira ML, Isern S, Michael SF, Lorenzana I, Yozwiak NL, MacInnis BL, Bosch I, Gehrke L, Zhang F, Sabeti PC
(2018) Field-deployable viral diagnostics using CRISPR-Cas13. Science, 360:444448. doi: 10.1126/science.aas8836

51. Pan L, Mu M, Ren HG, Yang P (2020) Clinical characteristics of COVID-19 patients with digestive symptoms in Hubei, China: a descriptive, cross-sectional, multicenter study. Am J Gastroenterol 115:766-773.

doi: 10.14309/ajg.0000000000000620

52. Perlman S, Netland J (2009) Coronaviruses post-SARS: Update on replication and pathogenesis. Nat Rev Microbiol 7:439450. doi: $10.1038 /$ nrmicro 2147

53. Peroni JF, Borjesson DL (2011) AntiInflammatory and Immunomodulatory Activities of Stem Cells. Veterinary Clinics of North America - Equine Practice 27:351-362. doi: 10.1016/j.cveq.2011.06.003

54. Su H, Yang M, Wan C, Yi L, Tang F, Zhu $\mathrm{H}$, Yi F, Yang H, Fogo AB, Nie X, Zhang C (2020) Renal histopathological analysis of 26 postmortem findings of patients with COVID-19 in China. Kidney Int 1-9. doi: 10.1016/j.kint.2020.04.003

55. Tai W, He L, Zhang X, Pu J, Voronin D, Jiang S, Zhou Y, Du L (2020) Characterization of the receptor-binding domain (RBD) of 2019 novel coronavirus: implication for development of RBD protein as a viral attachment inhibitor and vaccine. Cell Mol Immunol 17:613-620. doi:10.1038/s41423-020-0400-4

56. Tang $X, \mathrm{Wu}$ CLX, Song $Y$, Yao X, Wu X, Dung Y, Zhang H, Wang Y, Qian Z, Cui J, Lu J (2020b) On the origin and continuing evolution of SARS-CoV-2. Natl Sci Rev nwaa036. doi: 10.1093/nsr/nwaa036

57. Tetro JA (2020) Is COVID-19 receiving ADE from other coronaviruses? Microbe Infect 22:72-73. doi: 10.1016/j.micinf.2020.02.006

58. Triana-Baltzer GB, Gubareva LV, Nicholls 
JM, Pearce MB, Mishin VP, Belser JA, Chen LM, Chan RWY, Chan MCW, Hedlund M, Larson JL, Moss RB, Katz JM, Tumpey TM, Fang F (2009) Novel pandemic influenza $\mathrm{A}(\mathrm{H} 1 \mathrm{~N} 1)$ viruses are potently inhibited by DAS181, a sialidase fusion protein. PLoS ONE 4:12-14. doi: 10.1371/journal.pone.0007788

59. Van DN, Bushmaker T, Morris DH, Holbrook MG, Gamble A, Williamson BN, Tamin A, Harcourt JL, Thornburg NJ, Gerber SI, Lloyd-Smith JO (2020) Aerosol and surface stability of SARS-CoV-2 as compared with SARS-CoV-1. N Engl J Med 382:1564-1567. doi: 10.1056/NEJMc2004973

60. Vijaykrishna D, Smith GJD, Zhang JX, Peiris JSM, Chen H, Guan Y (2007) Evolutionary Insights into the Ecology of Coronaviruses. J Virol 81:4012-4020. doi: 10.1128/jvi.02605-06

61. Wang D, Hu B, Hu C, Zhu F, Liu X, Zhang J, Wang B, Xiang H, Cheng Z, Xiong Y, Zhao Y, Li Y, Wang X, Peng Z (2020) Clinical Characteristics of 138 Hospitalized Patients with 2019 Novel CoronavirusInfected Pneumonia in Wuhan, China. JAMA 323:1061-1069.

doi: 10.1001/jama.2020.1585

62. Wang M, Cao R, Zhang L, Yang X, Liu J, $\mathrm{Xu} \mathrm{M}$, Shi Z, Hu Z, Zhong W, Xiao G (2020) Remdesivir and chloroquine effectively inhibit the recently emerged novel coronavirus (2019-nCoV) in vitro. Cell Res 30:269-271. doi: 10.1038/s41422020-0282-0

63. Wang W, Xu Y, Gao R, Lu R, Han K, Wu G, Tan W (2020) Detection of SARS-CoV2 in Different Types of Clinical Specimens. JAMA 323:1843-1844. doi: 10.1001/jama.2020.3786

64. Wenzel RP, Edmond MB (2003) Managing SARS amidst uncertainty. N Engl J Med 348:1947-1948. doi: 10.1056/NEJMp030072

65. WHO (2020) Emergencies preparedness, response. Pneumonia of unknown origin China. Disease outbreak news. In: WHO Website. https://www.who.int/csr/don/05january-2020-pneumonia-of-unkowncause-china/en/. Accessed 06 April 2020

66. Wit ED, Doremalen NV, Falzarano D, Munster VJ (2016). REVIEWS SARS and MERS : recent insights into emerging coronaviruses. Nat Rev Microbiol 14:523534. doi: $10.1038 /$ nrmicro.2016.81

67. Worldometer Corona (2020) COVID-19 CORONAVIRUS PANDEMIC. In: Worldometer Corona https://www.worldometers.info/coronaviru/ Accessed 09 June 2020

68. Wu A, Peng Y, Huang B, Ding X, Wang X, Niu P, Meng J, Zhu Z, Zhang Z, Wang J, Sheng J, Quan L, Xia Z, Tan W, Cheng G, Jiang T (2020) Genome Composition and Divergence of the Novel Coronavirus (2019-nCoV) Originating in China. Cell Host Microbe 27:325-328. doi: 10.1016/j.chom.2020.02.001

69. Wu F, Zhao S, Yu B, Chen YM, Wang W, $\mathrm{Hu}$ Y, Song ZG, Tao ZW, Tian JH, Pei YY, Yuan ML, Zhang YL, Dai FH, Liu Y, Wang QM, Zheng JJ, Xu L, Holmes EC, Zhang YZ (2020) Complete genome characterisation of a novel coronavirus associated with severe human respiratory disease in Wuhan, China. BioRxiv 2020.01.24.919183.

doi: 10.1101/2020.01.24.919183

70. Wu Z, McGoogan JM

Characteristics of and Important Lessons from the Coronavirus Disease 2019 (COVID-19) Outbreak in China: Summary of a Report of 72314 Cases from the Chinese Center for Disease Control and Prevention. JAMA 323:1239-42. doi: 10.1001/jama.2020.2648

71. Xia S, Zhu Y, Liu M, Lan Q, Xu W, Wu Y, 
Ying T, Liu S, Shi Z, Jiang S, Lu L (2020)

Fusion mechanism of 2019-nCoV and fusion inhibitors targeting HR1 domain in spike protein. Cell Mol Immunol 1-3. doi: 10.1038/s41423-020-0374-2

72. Xiao F, Tang M, Zheng X, Liu Y, Li X, Shan H (2020) Evidence for Gastrointestinal Infection of SARS-CoV-2. Gastroenterology 158:1831-1833. doi: 10.1053/j.gastro.2020.02.055

73. Xie L, Sun C, Luo C, Zhang Y, Zhang J, Yang J, Chen L, Yang J, Li J (2020) SARSCoV-2 and SARS-CoV Spike-RBD Structure and Receptor Binding Comparison and Potential Implications on Neutralizing Antibody and Vaccine Development. BioRxiv 2020.02.16.951723. doi: 10.1101/2020.02.16.951723

74. Xiong C, Jiang L, Chen Y, Jiang Q (2020) Evolution and variation of 2019-novel coronavirus. BioRxiv 2020.01.30.926477. doi: org/10.1101/2020.01.30.926477

75. Yamamoto N, Yang R, Yoshinaka Y, Amari S, Nakano T, Cinatl J, Rabenau H, Doerr HW, Hunsmann G, Otaka A, Tamamura H, Fujii N, Yamamoto N (2004) HIV protease inhibitor nelfinavir inhibits replication of SARS-associated coronavirus. Biochem Bioph Res Co 318:719-25. doi: 10.1016/j.bbrc.2004.04.083

76. Yao X, Ye F, Zhang M, Cui C, Huang B, Niu P, Zhao L, Dong E, Song C, Zhan S, Lu R, Li H, Liu D, Clinical D, Liu D, Tan
W Liu D (2020) In Vitro Antiviral Activity and Projection of Optimized Dosing Design of Hydroxychloroquine for the Treatment of Severe Acute Respiratory Syndrome Main point: Hydroxychloroquine was found to be more potent than chloroquine at inhibiting SARS-CoV-2 in vit. Clin Infect Dis 2:1-25. doi: $10.1093 / \mathrm{cid} / \mathrm{ciaa} 237$

77. Zhou P, Yang XL, Wang XG, Hu B, Zhang L, Zhang W, Si HR, Zhu Y, Li B, Huang CL, Chen HD, Chen J, Luo Y, Guo H, Jiang RD, Liu MQ, Chen Y, Shen XR, Wang X, Zheng XS, Zhao K, Chen QJ, Deng F, Liu LL, Yan B, Zhan FX, Wang YY, Xiao GF, Shi ZL (2020) A pneumonia outbreak associated with a new coronavirus of probable bat origin. Nature 579:270 273. doi: 10.1038/s41586-020-2012-7

78. Zhu N, Zhang D, Wang W, Li X, Yang B, Song J, Zhao X, Huang B, Shi W, Lu R, Niu P, Zhan F, Ma X, Wang D, Xu W, Wu G, Gao GF, Tan W (2020) A novel coronavirus from patients with pneumonia in China, 2019. N Engl J Med 382:727733. doi: 10.1056/NEJMoa2001017 